\title{
MÄNGUSTATUd ÕPPETEGEVUSTE MÕJU ÜHEKSANDA KLASSI ÕPILASTE SUHTUMISELE EESTI KEELE KUI TEISE KEELE TUNDIDESSE
}

\author{
Mare Kitsnik, Pirgita-Maarja Hallas
}

\begin{abstract}
Ülevaade. Õpilaste eesti keele kui teise keele ebapiisava oskuse peapõhjuseks peetakse sageli madalat õpimotivatsiooni, mis arvatakse tulenevat kodust ja ühiskonnast ehk kultuurikontekstist. Samal ajal saab vähem tähelepanu hariduskonteksti, sh õppetundides toimuva mõju õpimotivatsioonile. Artiklis antakse ülevaade eksperimendist, mille käigus uuriti, kas ja kuidas mõjutavad õppetegevused õpilaste suhtumist eesti keele tundidesse, mis on oluline õpimotivatsiooni komponent. Kuuele üheksanda klassi õpperühmale õpetati kord nädalas eesti keelt ainult mängustatud õppetegevuste abil. Enne eksperimenti täitsid õpilased kirjaliku ankeetküsitluse, milles hindasid eesti keele tavatunde kümne teguri osas ja vastasid ka avatud küsimustele. Pärast eksperimenti täitsid õpilased küsimustiku, milles hindasid mängustatud tunde samade tegurite osas. Selgus, et õppetegevuste muutmine muutis õpilaste keskmist suhtumist eesti keele tundidesse. Mängustatud tunde peeti kokkuvõttes tavatundidest märgatavalt lõbusamaks ja kergemaks, samas aga vähem kasulikuks ja vajalikuks. Hinnangud mängustatud tundide mitmele aspektile varieerusid rühmiti üsna palju. Seejuures oli märgata seost hea tunniõhustiku ja tundidesse positiivse suhtumise vahel.*
\end{abstract}

Võtmesõnad: õpimotivatsioon, õppetegevused, mängustamine, teise keele õppimine, eesti keel

\section{Sissejuhatus}

Eesti keelt teise keelena õpetatakse üldhariduskoolis aktiivselt juba ligi kolmkümmend aastat. Kuigi õpilaste keeleoskus on aja jooksul paranenud, on arenguruumi veel palju. Keelekümblusprogrammis osalevad õpilased jõuavad põhikooli lõpuks üldiselt küllalt hea keeleoskustasemeni. Ülejäänud põhikoolinoorte ehk niinimetatud

\footnotetext{
* Artikli valmimist on toetanud teadus- ja arendusprojekt LLTOM18066 "Rändesõltuvus ja lõimumise väljakutsed
} 
tavaklasside õpilaste eesti keele oskuse tase jätab aga soovida. Põhikooli lõpueksami tulemused näitavad, et nõutava B1-keeleoskustaseme on saavutanud umbes 90\% keelekümblusklassis õppinutest ning vaid ligi 60\% tavaklassis õppinutest. (Selliov 2016, EIS) Seejuures on B1 iseseisva keelekasutaja madalam tase, millest jääb väheks gümnaasiumi keeruka eestikeelse aineõppega edukaks toimetulekuks. Arvestades tundide arvu, mis koolis eesti keele õppele kulub (kokku umbes 1000 tundi) peaks olema võimalik saavutada tunduvalt kõrgemaid eesmärke.

Sageli kõlab arvamus, et õpilaste vähese eesti keele oskuse põhipõhjus on madal sisemine õpimotivatsioon, mis tulenevat peamiselt kodust ja ühiskonnast ehk kultuurikontekstist (vt Metslang jt 2013). Kultuurikonteksti kõrval ei tohi aga unustada hariduskonteksti kui teist õpimotivatsiooni mõjutavat tegurit. Hariduskonteksti üks väga oluline komponent on õppetegevused, mis määravad suures osas õppijate suhtumise õpisituatsiooni ja mõjutavad sealtkaudu otseselt õpimotivatsiooni. Eesti keele õpetajad alahindavad sageli hariduskonteksti ja konkreetselt enda rolli õpilaste õpimotivatsiooni kujundamisel (Metslang jt 2013). Vaatlused näitavad, et eesti keele tavatundides kasutatakse siiani palju traditsioonilisi ja mittemotiveerivaid õppetegevusi, kuigi õpetajad ise enamasti nii ei arva (Metslang jt 2013, Novak 2019, Sooalu 2016). Niisiis on eesti keele kui teise keele õppemetoodikal ja õpetajakoolitusel arenguruumi.

Siinse uurimuse eesmärk on vaadelda, kas ja kuidas on õppetegevuste muutmise kaudu võimalik mõjutada õpilaste suhtumist eesti keele tundidesse, mis on üheks oluliseks õpimotivatsiooni määrajaks. Selleks on viidud läbi eksperiment, mille ajal üheksanda klassi õpilased õppisid eesti keelt innovatiivsete mängustatud õppetegevuste abil ning võrreldud õpilaste arvamusi eesti keele tavatundide ja mängustatud tundide kohta. Artikkel põhineb Pirgita-Maarja Hallase 2019. aastal Tartu Ülikoolis kaitstud samanimelisel magistritööl.

\section{2. Õppetegevuste mõju õpisituatsiooni suhtumisele ja ôpimotivatsioonile}

Teise keele omandamise ja õpimotivatsiooni uurija Robert Gardneri (2007) mudeli järgi kujundavad teise keele õpimotivatsiooni kultuurikontekst (ingl cultural context) ja hariduskontekst (ingl educational context). Hariduskontekst koosneb tervest koolisüsteemist, kuid eriti oluline roll on õppetundides toimuval - õpetaja isikul, õppematerjalidel ja õppetegevustel. Need määravad suures osas õpilaste suhtumise õpisituatsiooni, mis omakorda mõjutab otseselt õpimotivatsiooni. Zoltán Dörnyei rõhutab oma mudelis (1994) õpisituatsiooni tasandi olulisust õppija tasandi ja keele tasandi kõrval. Nii Gardneri kui ka Dörnyei mudelist on näha, et õpilaste suhtumine õppetunnis toimuvasse on oluline teise keele õpimotivatsiooni määrav tegur, mida õpetaja saab otseselt kujundada.

Peamine tegur tunnis, mis sõltub suurel määral õpetajast, on õppetegevuste (ingl learning activities) valik ja läbiviimine. Teise keele õppetegevused võib laias laastus jagada kaheks: traditsioonilised ja kommunikatiivsed. Traditsioonilised õppetegevused tulenevad grammatika-tõlkemeetodist (ingl grammar translation method), need on algselt tekkinud ladina keele õpetamiseks, kuid püsivad visalt siiani. Traditsioonilised õppetegevused on näiteks õpikuteksti tõlkimine, õpetaja 
küsimustele vastamine, sõnade ja väljendite õpetaja järel kordamine ja päheõppimine, õpetaja grammatikaseletuste kuulamine, kirjalike grammatikaharjutuste tegemine (lünka õige sõna või grammatilise vormi lisamine vms) (Larsen-Freeman 2007). Traditsiooniline õpe on ühetaoline ja võib õpilastele sageli tunduda igav ja ebameeldiv (Jean, Simard 2011, Sooalu 2016, Rüütel 2019).

Kommunikatiivsed óppetegevused on seotud kommunikatiivse lähenemisega (ingl communicative approach) teise keele õppele, mille eesmärgiks on eelkõige arendada õppijate suhtlusoskust. Kommunikatiivsete õppetegevuste liike on väga palju ja neid iseloomustab keele kasutamise harjutamine (vastandina teadmiste õppimisele keele kohta); seotus õppijate huvide ja eluliste vajadustega; autentsete ja autentselaadsete tekstide ja ülesannete kasutamine; keelefunktsioonide (mitte vaid vormide) õppimine; rohke suhtlemine paarides ja väikestes rühmades, keelelise sujuvuse arendamine, mitte ainult keelelisele täpsusele keskendumine. (Richards 2006) Uuringud on näidanud, et ka kommunikatiivsed õppetegevused ei meeldi ôppijaile alati ja tingimusteta (nt kui nad on liiga rasked, igavad või arusaamatu eesmärgiga) (Samperio jt 2016, Garrett, Shortall 2002, Bada, Okan 2000).

Meeldivaid õppetegevusi kirjeldades on uurijad välja toonud, et need peavad eelkõige olema õpilaste jaoks huvitavad ning tunduma neile kasulikud ja vajalikud (Dörnyei 1994). Huvitavad õppetegevused on üldjuhul autentsed või autentselaadsed, tänapäevased ning õppija jaoks tähenduslikud (Whittingham jt 2013). Õppetegevuste vajalikkuse ja kasulikkuse tajumine sõltub suuresti sellest, kas õppijad tunnevad, et nende keeleoskus areneb ja nad saavad õpitut ka väljaspool klassiruumi kasutada. Meeldivad õppetegevused on ka aktiivsed, energilised (Richards 2006, Kitsnik 2014) ning mitmekesised (Dörnyei 2001). Aktiivsus ja energilisus tähendab, et õpilased tegutsevad enamasti ise, mitte ei kuula ega jälgi vaid õpetajat või teisi õpilasi. Mitmekesisus tähendab, et tunnitegevused ja teemakäsitlused varieeruvad. Meeldivuse juures on oluline ka õppetegevuste paras raskusaste (Dörnyei 1994, Brophy 2016, Tomlinson 2012), st vastavus teise keele loomulikule arengurajale ning tasakaal väljakutse ja toetuse vahel.

Õppetegevuste läbiviimise õnnestumist mõjutab tugevalt ka õpiõhkkond, sh emotsioonid, mida õppijad tundides kogevad. Teise keele õppimisega kaasneb nii rõõm (ingl second language enjoyment) kui ka ärevus (ingl second language anxiety). Teise keele õppimine tekitab ärevust, sest õppijal on suur tõenäosus suhtlusega mitte toime tulla või endast imelik mulje jätta. Ärevust ei saa päriselt kaotada, kuid õpetaja saab aidata seda vähendada ja õppijatel sellega hakkama saada. (Horwitz jt 1986) Õpetaja saab ka muuta tunde rõõmsamaks. Kui õppetegevused on positiivsed ja kaasahaaravad, annab see õppijaile energiat ja julgust tulla toime uute keeleliste väljakutsetega (Dewaele 2015, 2005, Dörnyei, Murphy 2003). Samuti saab õpetaja teadlike tegevustega mõjutada rühmaliikmete omavahelisi suhteid ja kujundada sel viisil positiivset õpiõhkkonda (vt nt Hadfield 2010). 


\section{Mängustatud õppetegevuste roll ja mõju teise keele õppes}

Üks võimalus muuta õppetegevused meeldivamaks, on kasutada innovatiivset mängustamise meetodit (ingl gamification). Mängustamise mõiste tuleneb mängu mõistest. Mäng on tegevus, mida iseloomustab reaalsuse ja tinglikkuse samaaegne eksisteerimine, seotus lugude, tegevuse ja koostööga, väljakutsete olemasolu, täpse käigu ette mitteteadmine jm, mis kõik tekitab kaasahaaratust ja rõõmu ehk sisemist motivatsiooni ja energiat. Mängustamine on mänguelementide kasutamine tavapäraselt mittemänguliste tegevuste juures eesmärgiga kasutada tekkinud positiivne energia muude eesmärkide saavutamiseks (nt turunduses ostma meelitamiseks või hariduses õppimise soodustamiseks) (Hense jt 2013, Deterding jt 2011, Kim 2015, Sillaots 2016).

Olulised positiivset energiat tekitavad tegurid mängustatud tegevustes on väljakutset (ingl challenge) pakkuvad ülesanded, mis rahuldavad inimese psühholoogilisi põhivajadusi - vajadust eneseteostuse, saavutuste ja tunnustuse järele; vajadust end teistega võrrelda, vajadust teha koostööd ja tunda end hästi. (Schlagenhaufer, Amberg 2014, Sailer jt 2017) Mängustatud tegevuste käigus tekivad tegevusega tugevad emotsionaalsed seosed, mis soodustab ka info meeldejäämist (Mullins, Sabherwal 2018). Veel vähendab mängustamine õppimispinget - juhul, kui õppijad kohe eesmärki ei saavuta, ei järgne sellele läbikukkumistunnet, vaid on võimalus uuesti katsetada (Ur 2006). Mäng ja mängustamine aitavad kaasa ka hästitoimiva rühma tekkele, kuna eeldavad teiste kuulamist, igaühe panuse kasutamist ja üksteise toetamist ning ühiste emotsioonide tundmist (Lobman, Lundquist 2007).

Teise keele õppes saab kasutada nii lingvistilisi kui ka suhtluspõhiseid mängustatud tegevusi. Lingvistiliste tegevustega õpitakse peamiselt sõnavara ja grammatikat, mille täpseks omandamiseks on vaja neid palju korrata. Mängustatud tegevused aitavad muuta muidu tüütu kordamise lõbusaks ja põnevaks ning seetõttu motiveerivamaks. (Macedonia 2005, Gaudart 1999) Suhtlusmängud aitavad luua keelekasutusele elulise konteksti, tekitada autentselaadsed olukorrad, milles õppijad peavad erisuguseid suhtluseesmärke saavutama ning aitavad nii õppijal luua õpitavale enda jaoks tähenduse (Gaudart 1999, Spolin 1986, Lobman ja Lundquist 2007). Mängustatud suhtlustegevustes on suur osa improvisatsioonil. See tähendab, et inimene ei tea täpselt ette, kuidas mingi suhtlusolukord areneb ja mida ta peab rääkima (Lobman, Lundquist 2007, Kitsnik 2019) ning see sarnaneb päris eluga.

Uuringud on näidanud, et mängustatud tegevuste kasutamine teise keele õppes on üldiselt tulemuslik: muudab keele õppimise lihtsamaks ja kiiremaks, suurendab motivatsiooni ja vähendab õppimisega kaasnevat stressi (Gaudart 1999, Huyen, Nga 2013, Derakhshan, Khatir 2015, Macedonia 2005). Kui mängustamisel on esinenud negatiivne mõju, on see tavaliselt olnud seotud mängustatud tegevuse kehva ülesehituse ja läbiviimisega. Oluline on, et mängustatud tegevus haaraks osalejad kaasa ning pakuks neile parajat väljakutset (Ketterlinus 2017, Ojeda 2004, Sillaots 2016). Eesti keele kui teise keele täiskasvanute mängustatud suhtluskursuse väga positiivsetest kogemustest keeleõppesse suhtumise kujundamisel on kirjutanud Mare Kitsnik (2019). 


\section{Metoodika ja valim}

Eksperimendis osalesid 2018. aasta septembrist detsembrini ühe vene õppekeelega kooli üheksandate klasside kuue õpperühma õpilased ja nende eesti keele kui teise keele õpetaja, kes õpetas igale rühmale üks kord nädalas eesti kõnekeelt. Kõnekeeletund oli kooli korraldatud lisaks niinimetatud tavalistele eesti keele tundidele eesmärgiga arendada õpilaste rääkimisoskust. Eksperimendi ajal kasutas õpetaja kõnekeeletundides ainult mängustatud tegevusi.

Eksperimendis osalesid kolme üheksanda klassi õpilased. Üks üheksas klass jäi eksperimendist kõrvale, sest kool oli otsustanud sellele, nende hinnangul nõrgale ja probleemsele klassile, kõnekeeletunde mitte korraldada. Kõik eksperimendis osalenud klassid olid eesti keele tundideks jagatud kaheks õpperühmaks. Jagamine ei toimunud keeleoskustaseme või muu spetsiifilise näitaja alusel: kõigis rühmades oli eri keeleoskustasemega õpilasi, samuti oli igas õpperühmas nii poisse kui ka tüdrukuid.

Uurimuses osalenud õpetaja on hariduselt eesti filoloog ja õpetas eesti keelt teise keelena esimest aastat. Ta ei olnud varem töötanud üldhariduskoolis, kuid oli olnud õppejõud eri ülikoolides. Õpetaja suhtus mängustamisse väga positiivselt ja uskus, et mängustamine parandab õpimotivatsiooni ja arendab eesti keele suhtlusoskust kõige paremini. Õpetajal oli ka väike varasem kogemus eesti keele kui teise keele mängustatud õpetamisega. Ta oli töötanud kolme kuu jooksul assistendina firmas Game Club mängustatud-improvisatsioonilise eesti keele suhtluskursuse (autorid Mare Kitsnik ja Aleksei Razin, läbiviija Mare Kitsnik) juures.

Kõnekeeletunnis toimus enamik tegevusi väiksemates rühmades või paarides. Õpetaja alustas tundi mängulise soojendusharjutusega ning seejärel tehti mängustatud grammatika-, sõnavara- ja rääkimisharjutusi. Oma tundide ülesanded valis ja koostas ta ise, saades ideid vestlustest Kitsnikuga, raamatust "Mängime ja keel saab selgeks" (Kingisepp, Kärtner 2015), raamatust "Igrajut vse" (Razin, Kingisepp 2018), Kitsniku blogist "Rõõm keelest ja inimestest" (Rõõm...), koolitustelt ning ingliskeelsetest internetimaterjalidest. Vajaduse korral arendas õpetaja ülesandeid ise edasi, et need vastaksid paremini tema õpperühmadele ja õppe-eesmärkidele. Kõigis kuues rühmas tehti samu õppetegevusi, seejuures nii lingvistilisi kui ka suhtlustegevusi.

Õpilased täitsid enne eksperimendi algust ankeetküsitluse, millega uuriti nende suhtumist 8 aasta jooksul toimunud eesti keele kui teise keele tundidesse. Eksperimendi lõpus täitsid õpilased veidi muudetud ankeetküsitluse, millega uuriti nende suhtumist 4 kuu jooksul toimunud mängustatud kõnekeeletundidesse. Ankeetküsitluses vastasid õpilased avatud küsimustele ja hindasid eesti keele tunde Likert-tüüpi 7-pallise skaala abil kümne teguri osas: tundide vajalikkus (skaalal ebavajalik-vajalik), huvitavus (igav-huvitav), raskus (raske-kerge), tänapäevasus (vanamoodne-tänapäevane), lõbusus (tõsine-lõbus), energia (väsitav-energiat andev), mitmekülgsus (ühetaoline-mitmekülgne), aktiivsus (passïune-aktïune), kasulikkus (kasutu-kasulik), õhkkond (ebameeldiva õhkkonnaga-meeldiva õhkkonnaga). Avatud küsimustes paluti ôpilastel enne eksperimenti nimetada tundides tehtavaid õppetegevusi, mis meeldivad ja mis ei meeldi ning anda soovitusi, mida võiks eesti keele tundides teistmoodi teha. Pärast eksperimenti küsiti avatud küsimustes, millised õppetegevused õpilastele mängustatud tundides meeldisid ja 
miks, millised ei meeldinud ja miks ning mida võiks nende arvates kõnekeeletundides teisiti teha. Pärast eksperimenti täidetud ankeedis paluti õpilastel ka hinnata, mil määral aitasid kõnekeeletunnid kaasa nende kõnekeeleoskuse arengule. Need vastused anti viiepallisel skaalal: kindlasti ei, pigem ei, võib-olla, pigem jah, kindlasti jah. Ankeedid olid anonüümsed. Enne eksperimenti vastas ankeetküsitlusele 67 õpilast, pärast eksperimenti 77 õpilast.

Uurimismaterjali analüüsiti nii kvantitatiivselt kui ka kvalitatiivselt. Skaalaküsimustes on iga hinnatud teguri kohta arvutatud välja 1) üldine keskmine ja 2) iga õpperühma keskmine. Seejärel on hinnanguid analüüsitud 1) skaaladega hinnatud tegurite kaupa ja 2) õpperühmade kaupa. Vabade vastuste puhul on 1) leitud, kui palju iga teguri kohta käivaid vastuseid on antud, ja 2) analüüsitud vastuseid kvalitatiivse suunatud sisuanalüüsi abil.

\section{Tulemused}

\section{1. Õpilaste suhtumise võrdlus}

Ankeetküsitluses enne eksperimendi algust uuriti õpilaste suhtumist 8 aasta jooksul toimunud eesti keele kui teise keele tundidesse. Eksperimendi lõpus uuriti nende suhtumist 4 kuu jooksul toimunud mängustatud kõnekeeletundidesse. Õpilaste hinnangute võrdlust Likert-tüüpi skaalal kujutab joonis 1.

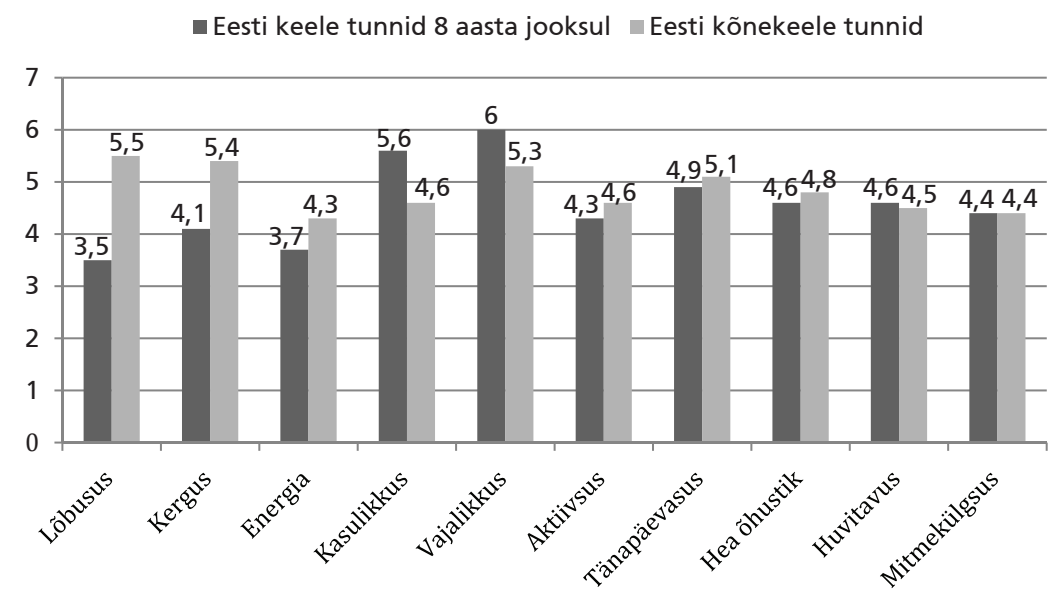

Joonis 1. Õpilaste hinnangud eesti keele kui teise keele tavatundidele ja eesti kõnekeele mängustatud tundidele

Nagu jooniselt 1 näha, hindasid õpilased eesti keele kui teise keele tavatundide vajalikkust ja kasulikkust kõrgelt. Hinnang tavatundide vajalikkusele on 7-pallisel skaalal 6 palli ja hinnang kasulikkusele 5,6 palli. Seega ületasid need hinnangud selgelt skaala keskmist ehk 4 palli. Mõnevõrra üle keskmise on õpilased hinnanud ka seniste eesti keele tundide tänapäevasust ( 4,9 palli) ja huvitavust ( 4,6 palli). Ka hinnang tundide õhkkonna meeldivusele on üle keskmise: 4,6 palli. Ligikaudu 
keskmiseks hinnati tundide mitmekülgsust (4,4 palli), aktiivsust ( 4,3 palli) ja kergust (4,1 palli). Alla keskmise on seniste eesti keele tundide puhul hinnatud kaht tegurit - energiat ja lõbusust. Keskmiseks hinnanguks tundide energiale kujunes 3,7 palli. Kõige madalamalt on hinnatud eesti keele tavatundide lõbusust: 3,5 palliga.

Mängustatud tundidele antud hinnangud ületavad, erinevalt tavatundide hinnangutest, kõik skaala keskmist ehk nelja palli. Kõige kõrgemaks kujunes hinnang mängustatud tundide lõbususele (5,5 palli), kergusele (5,4 palli) ja vajalikkusele (5,3 palli). Mängustatud kõnekeele tundide tänapäevasust hinnati keskmiselt 5,1 palliga, õhustiku meeldivust 4,8 palliga, nii tundide kasulikkust kui ka aktiivsust 4,6 palliga ning huvitavust 4,5 palliga. Kõige madalama keskmise hinnangu pälvisid mängustatud tundide mitmekülgsus (4,4 palli) ja energia (4,3 palli).

Kui võrrelda mängustatud kõnekeele tundidele antud hinnanguid tavatundide hinnangutega, eristub kolm tegurite gruppi: 1) tundide lõbusus, kergus ja energia, millele antud hinnang oli mängustatud tundidel selgelt kõrgem kui tavatundidel, 2) tundide aktiivsus, hea õhustik, tänapäevasus, mitmekülgsus ja huvitavus, mille üldine keskmine hinnang erines tavatundide ja mängustatud tundide puhul vähe, ja 3) tundide kasulikkus ja vajalikkus, mille hinnang oli mängustatud tundide puhul selgelt madalam kui tavatundidel.

Kõige suurem erinevus tavatundidesse ja mängustatud tundidesse suhtumises oli lõbususe osas, millele antud keskmine hinnang oli mängustatud tundidel kaks palli kõrgem kui tavatundidel (tavatunnid 3,5 ja mängustatud tunnid 5,5 palli). Kui eesti keele tavatunnid on õpilaste jaoks pigem tõsised, siis mängustatud tunnid on üsna lõbusad. Mängustatud tunnid on ka 1,3 palli võrra kergemad kui tavatunnid (tavatunnid 4,1 ja mängustatud tunnid 5,4 palli). Samuti on mängustatud tunnid tavatundidest 0,6 palli võrra energilisemad (tavatunnid 3,7 ja mängustatud tunnid 4,3 palli), kuid energia jääb siiski skaala keskmise piiresse.

Tavatundidega võrreldes hinnati mängustatud kõnekeeletunde selgelt vähem kasulikuks (tavatunnid 5,6 ja mängustatud tunnid 4,6, vahe 1 pall). Samuti anti madalam hinnang mängustatud tundide vajalikkusele (tavatunnid 6 ja mängustatud tunnid 5,3 palli, vahe 0,7 palli). Seega, kui eesti keele tavatunde peetakse väga vajalikuks ja kasulikuks, siis mängustatud tundide vajalikkuses ja kasulikkuses ollakse mõnevõrra vähem kindlad.

\subsection{Mängustatud tundide eelised}

Mängustatud kõnekeeletundide puhul said tavatundidest selgelt kõrgema hinnangu kolm tegurit: lõbusus (5,5 vs. tavatundidel 3,5 palli), kergus (5,4 vs. 4,1 palli) ja energia (4,3 palli vs. 3,7 palli) (vt joonis 1). Järgnevalt on neist lähemalt vaadeldud lõbusust ja kergust.

\subsubsection{Tundide Iõbusus}

Võrreldes tavatundidega hinnati mängustatud tunde tunduvalt lõbusamaks. Kui tavatunde hinnati pigem tõsiseks (keskmine hinnang 3,5 palli ehk alla skaala keskmise), siis mängustatud tunde hinnati lõbusaks (keskmine hinnang 5,5 palli ehk 
2 palli kõrgem). Joonisel 2 on kujutatud võrdlevalt tavatundide ja mängustatud tundide lõbususe hinnangud õpperühmade kaupa.

Tavatundide lõbususe hinnang erineb rühmiti päris palju. Kõige tõsisemaks hindasid oma tavatunde rühma D õpilased (2,8 palli) ja kõige lõbusamaks rühma A õpilased (4,5 palli). Seega on madalaima ja kõrgeima hinnangu vahe 1,7 palli. Kõik rühmad peale A hindavad seejuures tavatunde pigem tõsiseks ehk hinnang on alla skaala keskmise. Vabades vastustes ei kommenteeritud tavatundide lõbusust kordagi.

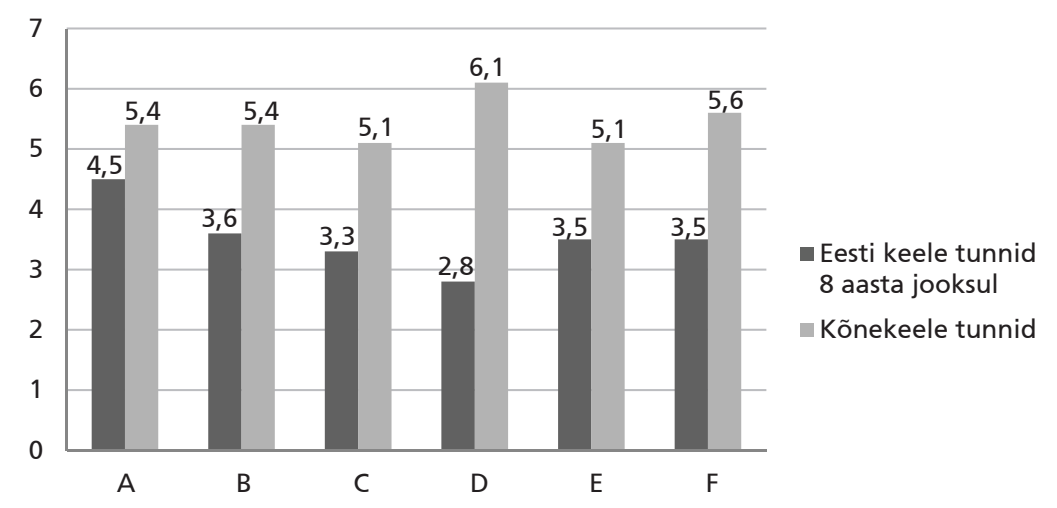

Joonis 2. Tundide lõbusus: õpilaste hinnangud õpperühmade kaupa

Mängustatud tundide lõbususe osas ollakse üksmeelsemad. Madalaima hinnangu (5,1, rühmad C ja E) ja kõrgeima (6,1, rühm D) vahe on 1 pall. Viie rühma hinnangud (kõigil peale D) jäävad 5,1-5,6 palli vahele. Kõigi rühmade arvates on mängustatud tunnid tavatundidest lõbusamad. Kõige suurem vahe hinnangus mängustatud tundidele võrreldes tavatundidega oli rühmal $\mathrm{D}$ (3,3 palli), kes pidas tavatunde kõige tõsisemaks ja kõige väiksem rühmal A (o,9 palli), kes hindas tavatunde kõige lõbusamaks.

Õpilased kommenteerisid mängustatud kõnekeeletundide lõbusust ka vabades vastustes. Neile meeldis, et mängustatud tegevused olid lõbusad ja võimaldasid praktiseerida keelt tavapärasest erinevas vormis.

(1) Erinevad mängud. Neid on lõbus mängida. Saab lõbusalt praktiseerida keelt. (A-rühm)

(2) Tavatundides on kõik tõsisem ja keerulisem, aga kõnekeeletund on teistsuguses vormis ja ei ole raske lõpuni vastu pidada (F-rühm)

Nimetati ka konkreetseid tegevusi.

(3) Ülespoomine oli üsna lõbus. Jututäringutega tulid naljakad lood. (B-rühm)

Esines ka ettepanekuid, et mängustatud tunnid tuleks teha veelgi lõbusamaks või vastupidi, et tunnid peaksid olema tõsisemad.

(4) Oleks vaja muuta tund lõbusamaks. (E-rühm)

(5) Mulle ei meeldi, et me pidevalt mängime mänge, aga tõsiseid ülesandeid, nagu vestlemine, ümberjutustus, kuulamine me ei tee. (C-rühm) 


\subsubsection{Tundide kergus}

Eesti keele tavatunde pidasid õpilased raskuselt keskmiseks - üldine keskmine oli 4,1 Võrreldes tavatundidega hinnati mängustatud tunde selgelt kergemaks - üldine keskmine 5,4. Joonisel 3 on kujutatud võrdlevalt tavatundide ja mängustatud tundide kerguse hinnangud õpperühmade kaupa.

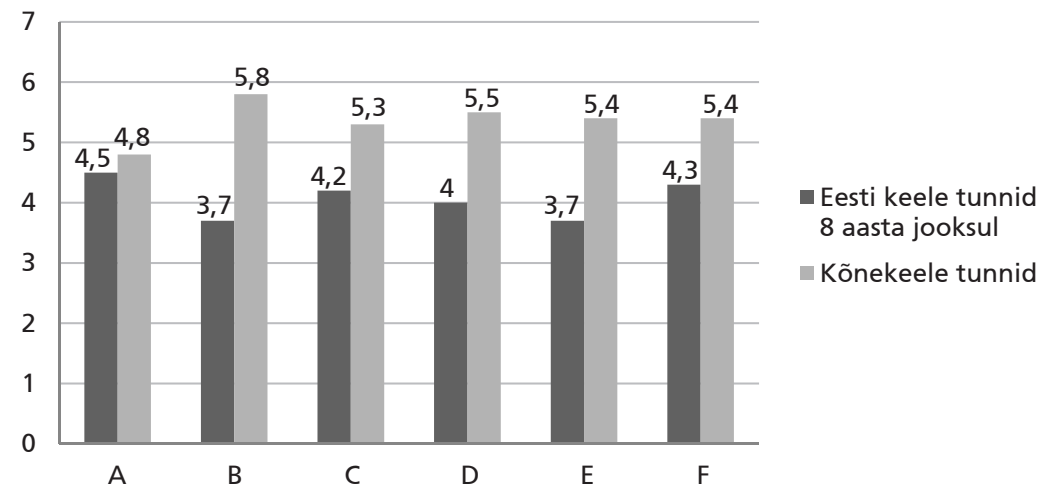

Joonis 3. Tundide kergus: õpilaste hinnangud õpperühmade kaupa

Kõige raskemaks pidasid oma tavatunde rühmad B ja E (hinnang 3,7 palli ehk alla skaala keskmise) ja kõige kergemaks rühma A õpilased (4,5 palli ehk üle skaala keskmise). Seega jäävad rühmade hinnangute erinevused 0,8 palli piiresse.

Mängustatud tunde pidasid tavatundidest kergemaks kõik rühmad. Kõige kergemaks pidas mängustatud tunde rühm B (5,8 palli) ja kõige vähem kergeks rühm A (4,8 palli). Seega jäi rühmade hinnangute erinevus 1 palli piiresse ja kõnekeeletunde hinnati keskmisest veidi kergemast kuni üsna kergeni. Seega oli ka siin märgata sarnane tendents, mis lõbususe hindamise juures. B-rühm ehk üks kahest rühmast, kus hinnati tavatundide kergust kõige madalamalt, hindas mängustatud tundide kergust kõige kõrgemaks. Rühm A, kus hinnati tavatundide kergust kõige kõrgemalt, hindas mängustatud tundide kergust kõige madalamalt. Kõige rohkem muutus mängustatud tundide kerguse hinnangus võrreldes tavatundidega rühmal B (hinnang tavatundidele 3,7 ja mängustatud tundidele 5,8 palli ehk 2,1 palli kõrgem) ja kõige väiksem muutus rühmal A (hinnang tavatundidele 4,5 ja mängustatud tundidele 4,8 palli ehk tõus 0,3 palli).

Õpilased kommenteerisid mängustatud tundide kergust ka vabades vastustes. Korduvalt toodi välja, et mängustatud kõnekeeletunnid on tavatundidest kergemad.

(6) Kõnekeel on meelelahutuslik tund - me ei tee mingeid raskeid ülesandeid ja 80\% tunnist möödub nagu mäng. (B-rühm)

Samal ajal tundusid osale õpilastest mängustatud harjutused kohati liiga kerged ja seetõttu mittearendavad.

(7) Väga nõrk programm. Igaüks teab sellel tasemel keelt, ka uus tüdruk, kes on eesti keelt õppinud vaid 2,5 aastat. (F-rühm)

(8) Väga vähe on harjutusi sõnavara arendamiseks. Tahaks õppida rohkem uusi, raskeid sõnu. (A-rühm) 
(9) Tunnid on huvitavad, aga mängud võib teha natuke raskemad. (B-rühm)

Mängustatud tundide puhul kerkis esile ka probleem õpilaste erineva keeletasemega.

(10) Kui sind pannakse kokku kellegagi, kes on sinust targem, jääd naerualuseks. (C-rühm)

\subsection{Mängustatud tundide puudused}

Mängustatud kõnekeeletundide puhul said tavatundidest selgelt madalama hinnangu kaks tegurit: kasulikkus ( 4,6 vs. tavatundidel 5,6 palli) ja vajalikkus ( 5,3 palli vs. 6 palli) (vt joonis 1). Järgnevalt on neist lähemalt vaadeldud tundide kasulikkust.

Eesti keele tavatunde pidasid oppilased kasulikuks: üldine keskmine on 5,6. Võrreldes tavatundidega hinnati mängustatud tunde vähem kasulikuks (üldine keskmine 4,6). Joonisel 4 on kujutatud võrdlevalt tavatundide ja mängustatud tundide kasulikkuse hinnangud õpperühmade kaupa.

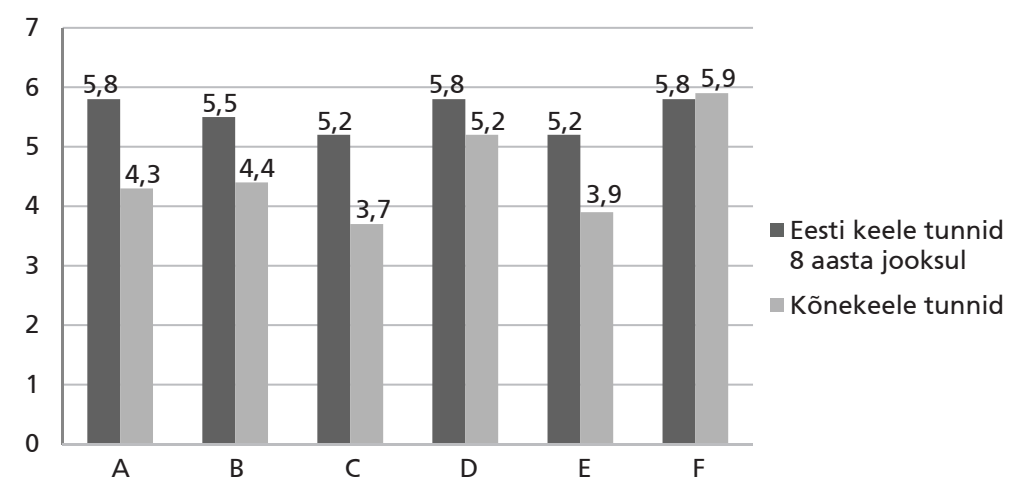

Joonis 4. Tundide kasulikkus: õpilaste hinnangud õpperühmade kaupa

Kõik rühmad hindasid tavatundide kasulikkust ühtlaselt ja üsna kõrgelt. Kõige kasulikumaks pidasid tavatunde rühmad A, D ja F (kõigi hinnang 5,8 palli) ning kõige madalamaks rühmad C ja E 5,2 palliga. Seega jäävad tavatundide kasulikkuse hinnangud o,6 palli piiresse ja ületavad kõik viit palli.

Ainult rühm F hindas mängustatud tunde tavatundidest kasulikumaks (hinnang tavatundidele 5,8 ja mängustatud tundidele 5,9 palli). Kõik teised rühmad hindasid mängustatud tundide kasulikkust selgelt tavatundide kasulikkusest madalamaks. Kõige suurem erinevus tava- ja mängustatud tundide hinnangus oli rühmadel A ja C (mängustatud tunnid 1,5 palli madalama hinnanguga kui tavatunnid). Kokkuvõttes on hinnang mängustatud tundide kasulikkusele rühmiti väga erinev, hinnangud erinevad koguni 2,2 palli piires. Rühmad F ja D hindasid kõnekeeletunde selgelt üle keskmise kasulikuks, rühmad A ja B veidi üle keskmise kasulikuks ja kaks rühma $\mathrm{C} \mathrm{ja} \mathrm{E}$ veidi alla keskmise kasulikuks.

Vabades vastustes avaldasid õpilased mängustatud tundide kasulikkuse kohta palju arvamust ja vastused olid väga vastandlikud. Õpilased, kes pidasid mängustatud tunde vähekasulikuks, väitsid, et ei õpi seal midagi uut ega valmistu ka eksamiks. 
(11) Peaaegu kõik, mis me seal teeme, on igav ja mittekasulik. (E-rühm)

(12) Eesti keele tunnist on mul abi, aga kõnekeeletund on kasutu, me ei saanud sealt mitte midagi uut teada. (E-rühm)

(13) Seesugune õpetamine ei soodusta üldiselt aktiivset eesti keele õppimist, kuigi mõned sõnad meenuvad. Võimalik, et aja jooksul kõnelemine areneb, aga tavatunnid on selles mõttes kasulikumad. (A-rühm)

Samal ajal pidasid teised õpilased kõike tunnis tehtut arendavaks ja kasulikuks.

(14) Mulle meeldib, kui me mängime igasuguseid mänge, siis jäävad sõnad ja muu informatsioon paremini meelde. (F-rühm)

(15) Mängud aitavad arendada mõtlemist. (B-rühm)

(16) Ma tahan öelda "aitäh", sest see arendab mu rääkimisoskust eesti keeles. (A-rühm)

\subsection{Mängustatud tundide samaväärsus tavatundidega}

Mängustatud kõnekeeletunnid ei erinenud oluliselt tavatundidest viie teguri poolest: tundide aktiivsus (4,6 vs. tavatundidel 4,3 palli), tänapäevasus (5,1 palli vs. 4,9 palli), huvitavus (4,5 palli vs. 4,6 palli), mitmekesisus (4,4 palli vs. 4,4 palli) ja hea õhustik (4,8 palli vs. 4,6 palli) (vt joonis 1). Samal ajal olid rühmadevahelised erinevused kohati üsna suured. Järgnevalt on lähemalt vaadeldud hinnanguid tundide heale õhustikule.

Tundide õhustiku headuse keskmine hinnang tavatundidel oli 4,6 ja mängustatud tundidel 4,8. Joonisel 5 on kujutatud võrdlevalt tavatundide ja mängustatud tundide õhustiku hinnangud õpperühmade kaupa.

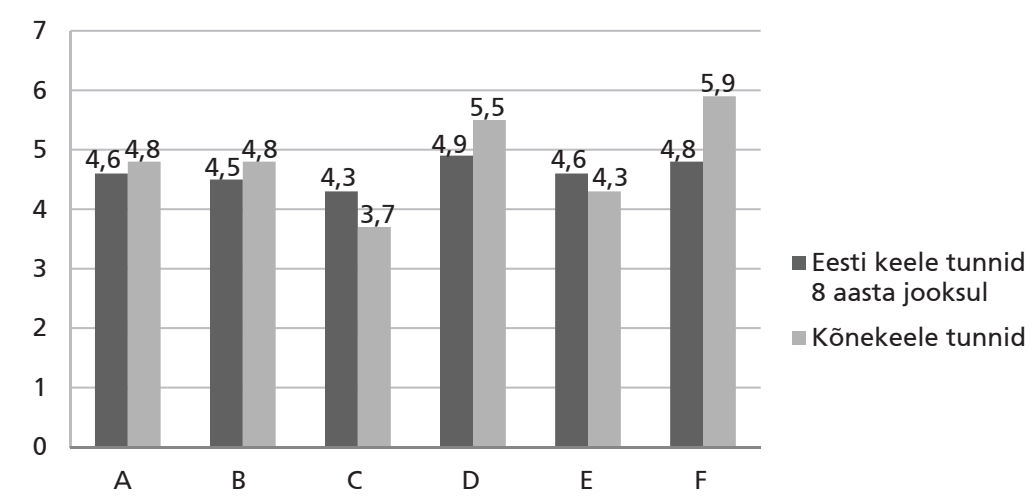

Joonis 5. Tundide hea õhustik: õpilaste hinnangud õpperühmade kaupa

Hinnangud tavatundide õhustikule olid üsna ühtlased. Kõige paremaks hindas õhustikku rühm D (4,9 palli) ning kõige madalamalt rühm C (4,3 palli). Seega jäid kõigi rühmade vastused o,6 palli piiresse.

Mängustatud tundide õhustiku hinnangud erinesid aga rühmiti tunduvalt enam. Kõige madalama (rühmal C 3,7 palli) ja kõrgema (rühmal F 5,9 palli) hinnangu 
vahe oli 2,2 palli. Hinnang õhustiku meeldivusele oli mängustatud tundide puhul võrreldes tavatundidega madalam kahel rühmal ja kõrgem neljal. Vabades vastustes toodi korduvalt esile kõnekeeletunni positiivset õhkkonda.

(17) Kõnekeeletunnis saab lõõgastuda ja see tõstab tuju. (A-rühm)

(18) Selline tund aitab puhata pidevast pingest. (B-rühm)

(19) Kõnekeeletunnis on õhkkond vabam, saab kasutada fantaasiat, mängida. (D-rühm)

Samal ajal häiris aga osa õpilasi distsipliini puudumine ja lärm tunnis.

(20) Õpetaja on väga hea, kui mulle miski ei meeldi, siis on need mõned õpilased. (C-rühm)

(21) Mulle ei meeldi distsipliin tunnis. Osa inimesi peab end lärmakalt üleval. (A-rühm)

\section{5. Õpperühmade hinnangud}

Vaadeldud on ka iga õpperühma hinnanguid eraldi ning võrreldud seejärel rühmi omavahel. Selgus, et kaks rühma (F ja D) hindasid mängustatud kõnekeeletunde üldisest keskmisest kõrgemalt, kaks rühma (B ja A) üldise keskmisega ligikaudu võrdselt ja kaks rühma ( $\mathrm{C}$ ja E) üldisest keskmisest madalamalt. Mõningane varieerumine esines seejuures igas rühmas ka indiviiditi. Järgnevalt on vaadeldud võrdlevalt rühmade $\mathrm{C}$ ja $\mathrm{F}$ hinnanguid, mis on kujutatud joonisel 6.

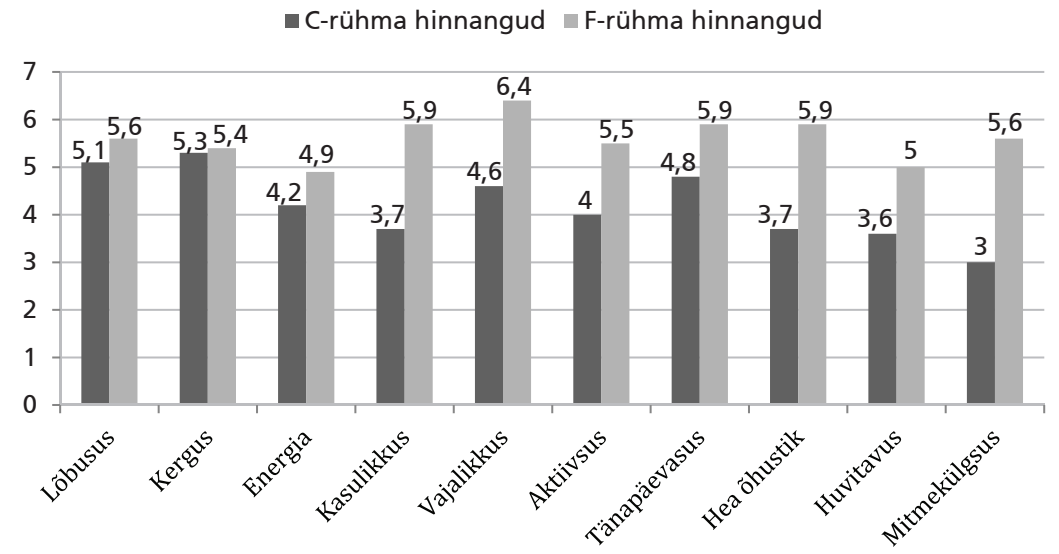

Joonis 6. Õpilaste hinnangud õpperühmade kaupa (C- ja F-rühm)

Nagu jooniselt 6 näha, hindasid C- ja F-rühma õpilased peaaegu võrdselt vaid mängustatud tundide kergust: rühm $\mathrm{C} 5,3$ palliga ja rühm $\mathrm{F} 5,4$ palliga. See sarnaneb ka üldise keskmisega, mis oli samuti 5,4. Mängustatud tundide kerguse hinnang võrreldes tavatundidega oli kummalgi rühmal samuti võrdselt ehk 1,1 palli kõrgem, sarnanedes samuti üldise keskmisega. Mängustatud tundide lõbusust hindas F-rühm 5,6 palliga, mis on üldise keskmise sarnane. C-rühm hindas sama tegurit mõnevõrra madalamalt - 5,1 palliga. Hinnang mängustatud tundide energiale oli 
C-rühmal 4,2 palli, mis sarnaneb üldise keskmisega ja F-rühmal üle keskmise ehk 4,9 palli.

Mängustatud tundide kasulikkust hindas rühm C kõigist rühmadest kõige madalamalt ehk 3,7 palliga. Ka mängustatud tundide vajalikkuses ei olnud C-rühm väga kindel - hinnang 4,6 palli. F-rühm aga hindas ainukesena mängustatud tunde tavatundidest isegi veidi kasulikumaks - hinnang 5,9 palli ja vajalikumaks - hinnang 6,4 palli. Ka kõigi ülejäänud viie teguri hinnangud on F-rühmal C-rühmast selgelt kõrgemad. Mängustatud tundide huvitavust hindas rühm C 3,6 palliga ja aktiivsust 4 palliga. Samal ajal hindas rühm F huvitavust 5 palliga ja aktiivsust 5,5 palliga. Mängustatud tundide tänapäevasuse hinnang on rühmal C 4,8 palli ja rühmal $\mathrm{F} 5,9$ palli. Kõige suurem erinevus on C- ja F-rühma hinnangutes mängustatud tundide mitmekülgsusele. Kui C-rühm hindas seda tegurit 3 palliga, siis F-rühm 5,6 palliga. Samuti on väga erinevad C- ja F-rühma hinnangud tundide heale õhustikule. C-rühm hindas õhustikku 3,7 palliga, mis on selgelt alla üldise keskmise. F-rühma hinnang oli aga 5,9 palli ehk tunduvalt üle keskmise.

Pärast eksperimenti esitatud küsimusele mängustatud tundide kasust kõnekeele arengule kujunes C-rühma keskmiseks hinnanguks viiepallisel skaalal 2 ehk pigem mitte. Rühma F keskmine hinnang samale küsimusele oli aga 3,9 ehk pigem jah.

Vabades vastustes tõid paljud C-rühma õpilased välja, mis neile mängustatud kõnekeeletundides ei meeldinud ning F-rühma õpilased, miks need tunnid neile meeldisid.

(22) Mulle ei meeldi meie õpetaja õpetamise meetod, me ei teinud ühtegi teksti, dialoogi jne. Ma arvan, et õpetaja tuleks välja vahetada või peaks ta hakkama õpetama kuidagi teisiti (C-rühm)

(23) Ma põhimõtteliselt ei taha seda keelt õppida. (C-rühm)

(24) Tund on liiga lärmakas, mitte midagi ei saa aru. Progressi ei ole. (C-rühm)

(25) Kõnekeeletund on suunatud sõnavara suurendamisele ja suhtlemisjulgusele, tavatund on rohkem grammatikast. Kõnekeeletunnis me keskendume rohkem keelekasutuse sujuvusele ja õpime keelt terviklikult. Tavatunnis me õpime grammatikat ja õigekirja, aga kõnekeeletunnis me õpime õigesti rääkima ja oma mõtteid väljendama. (F-rühm)

(26) Mulle täielikult meeldib tund, kus me ainult räägime. Meil on väga hea õpetaja. Mulle üleüldiselt meeldib tund, ilma mingisuguste eelistusteta. (F-rühm)

\section{Kokkuvõte}

Õpilaste eesti keele kui teise keele oskuse tase jätab sageli soovida ja selle üheks peapõhjuseks peetakse madalat õpimotivatsiooni, mis arvatakse tulenevat kultuurikontekstist (ehk kodust ja ühiskonnast). Vähem tähelepanu pööratakse aga hariduskontekstile ehk koolisüsteemis tervikuna ja eriti konkreetsetes tundides toimuva mõjule eesti keele õpimotivatsiooni kujundamisel. Käesoleva uuringu eesmärk oli vaadelda, kas ja kuidas on võimalik innovatiivsete mängustatud õppetegevuste abil mõjutada õpilaste suhtumist eesti keele tundidesse kui õpimotivatsiooni üht olulist tegurit.

Kolme 9. klassi kuus õpperühma õppisid nelja kuu jooksul üks kord nädalas lisaks eesti keele tavatundidele eesti keelt kõnekeeletundides, milles kasutati vaid 
mängustatud tegevusi. Õpilased ei olnud rühmadesse jagatud keeleoskustaseme või mingite muude spetsiifiliste näitajate alusel. Kõnekeeletundide õpetajal oli väike eesti keele teise keelena õpetamise kogemus, kuid ta oli väga motiveeritud tunde mängustama. Õpetaja koostas oma tunnikavad ise, kasutades selleks olemasolevaid allikaid (mängude käsiraamatud ja internetimaterjalid jm). Õpilaste hinnanguid tavatundidele ja mängustatud tundidele uuriti ankeetküsitluse abil, milles olid Likert-tüüpi skaalaküsimused (seitsmepallisel skaalal) ning vaba vastust nõudvad küsimused tundide vajalikkuse, kasulikkuse, lõbususe, energia, kerguse, huvitavuse, mitmekülgsuse, aktiivsuse, tänapäevasuse ja hea õhustiku kohta. Tulemusi analüüsiti nii kvantitatiivselt kui ka kvalitatiivselt.

Mängustatud tundide üldised keskmised hinnangud olid kõrgemad võrreldes tavatundidega kolme teguri (lõbususe, kerguse ja energia) osas ning madalamad kahe teguri (kasulikkuse ja vajalikkuse) osas. Seejuures erinesid eri rühmade hinnangud mõnevõrra. Ülejäänud viie teguri (aktiivsuse, energia, huvitavuse, mitmekülgsuse ja hea õhustiku) osas olid üldised keskmised hinnangud küll enam-vähem võrdsed, kuid erinesid seejuures rühmiti. Õnnestumiseks võib pidada asjaolu, et tavapäraselt tõsisevõitu eesti keele tunnid õnnestus mängustamisega muuta palju lõbusamaks (tavatundide keskmine hinnang 3,5 palli ja mängustatud tundide keskmine hinnang 5,5 palli) ja ka veidi energilisemaks. See on oluline, sest rõõmul ja energial on suur mõju õpimotivatsioonile ja õppimise tõhususele.

Mängustamine muutis eesti keele tunnid ka kergemaks (tavatundide keskmine hinnang 4,1 palli ja mängustatud tundidel 5,4 palli), kuid selle tulemuse positiivsuses ei saa olla väga kindel, sest kohati tundsid õpilased, et tegevuste keeleline tase on nende jaoks liiga madal ja nad ei õpi midagi juurde. See oli ka ilmselt üheks põhjuseks, miks hinnang mängustatud tundide vajalikkusele ja kasulikkusele oli selgelt tavatundide hinnangust madalam (tavatundide vajalikkuse hinnang 6 ja kasulikkuse hinnang 5,6 palli ning mängustatud tundidel vastavalt 5,3 ja 4,6 palli).

Kaks õpperühma hindasid mängustatud tunde kõigi rühmade üldisest keskmisest kõrgemalt, kaks õpperühma üldise keskmisega enam-vähem võrdselt ja kaks õpperühma üldisest keskmisest madalamalt. Mõningane varieerumine esines seejuures igas rühmas ka indiviiditi. Märgatav oli õpiõhustiku mõju hinnangutele. Rühmad, kes pidasid mängustatud tundide õhustikku tavatundide õhustikust paremaks, hindasid ka mängustatud tunde tervikuna kõrgelt. Rühmadele, kes pidasid mängustatud tundide õhustikku halvemaks kui tavatundides, ei meeldinud mängustatud tunnid ka tervikuna.

Kokkuvõttes võib öelda, et mängustamise abil on võimalik muuta õpilaste suhtumist eesti keele tundidesse ja seega mõjutada ka õpimotivatsiooni. Niisiis on mängustamisel eesti keele kui teise keele õppemetoodika arendamisel potentsiaali. Mängustatud ülesanded peavad aga vastama õpilaste eale ja keeletasemele ning olema päriselt kaasahaaravad, mitmekülgsed ja vaheldusrikkad. Õpilasi on vaja suunata teadvustama keeleoskuse arengu aspekte ja mõistma, mis meetodid mil viisil keeleoskust arendavad. Mängustamist ei pea kasutama kogu aeg, see sobib väga hästi teiste meetoditega kombineeritult. Õpetaja peab oskama mängustatud õppetegevusi tegevat rühma juhtida: innustada, reeglite järgimist jälgida, parajat toetust anda ning positiivset õpiõhkkonda luua. 


\section{Viidatud kirjandus}

Bada, Erdogan; Okan, Zuhan 200o. Students' language learning preferences. - TESL- EJ, 4 (3), $1-15$.

Brophy, Jere 2016. Kuidas õpilasi motiveerida. Käsiraamat õpetajatele ['Motivating Students to Learn']. Tallinn: Archimedes.

Derakhshan, Ali; Khatir, Elham Davoodi 2015. The Effects of Using Games on English Vocabulary Learning. - Journal of Applied Linguistics and Language Research, 2 (3), 39-47.

Deterding, Sebastian; Dixon, Dan; Khaled, Rilla; Nacke, Lennart 2011. From game design elements to gamefulness: Defining "gamification". - Proceedings of the 15th International Academic Mind Trek Conference: Envisioning Future Media Environments. MindTrek '11. 28-30 September, Tampere, Finland. https://doi.org/10.1145/2181037.2181040

Dewaele, Jean-Marc 2005. Investigating the psychological and the emotional dimensions in instructed language learning: Obstacles and possibilities. - The Modern Language Journal, 89 (3), 367-380. https://doi.org/10.1111/j.1540-4781.2005. 00311.X

Dewaele, Jean-Marc 2015. On emotions in foreign language learning and use. - JALT2015 Coference Article. The Language Teacher, 39 (3), 13-15. https://doi.org/10.37546/ JALTTLT39.3-3

Dörnyei, Zoltán 1994. Motivation and motivating in the foreign language classroom. - The Modern Language Journal, 78 (3), 273-284. https://doi.org/10.1111/j.1540-4781.1994. tb02042.x

Dörnyei, Zoltán 2001. The Motivational Strategies in the Language Classroom. Cambridge University Press. https://doi.org/10.1017/CBO9780511667343

Dörnyei, Zoltán; Murphey, Tim 2003. Group Dynamics in the Language Classroom. Cambridge Language Teaching Library. https://doi.org/10.1017/CBO9780511667138

EIS = Eksamite infosüsteem ['Examination Information System']. https://eis.ekk.edu.ee/ eis/eksamistatistika (21.8.2019).

Game Club. Mitteformaalne koolituskeskus. http://www.thegameclub.eu (21.8.2019).

Gardner, Robert C. 2007. Motivation and second language acquisition. - Porta Linguarum, 8, 9-20.

Garrett, Peter; Shortall, Terry 2002. Learners' evaluations of teacher-fronted and studentcentred classroom activities. - Language Teaching Research, 6 (1), 25-57. https:// doi.org/10.1191/1362168802lrog6oa

Gaudart, Hyacinth 1999. Games as teaching tools for teaching English to speakers of other languages. - Simulation \& Gaming, 30 (3), 283-291. https://doi.org/10.1177 \%2F104687819903000304

Hadfield, Jill 2010. Rühmadünaamika võõrkeeletunnis ['Classroom Dynamics']. Tallinn: Argo.

Hallas, Pirgita-Maarja 2019. Mängustatud õppetegevuste mõju üheksanda klassi õpilaste suhtumisele eesti keele kui teise keele tundidesse ['The effect of gamified learning activities on the attitudes of 9 th grade pupils towards Estonian as a second language school lessons']. Magistritöö. Tartu Ülikool. http://hdl.handle.net/10062/65169

Hense, Jan; Sailer, Michael; Mandl, Heinz; Klevers, Markus 2013. Psychological perspectives on motivation through Gamification. - Interaction Design and Architecture(s) Journal, 19, 18-37.

Horwitz, Elaine K.; Horwitz, Michael B.; Cope, Joann 1986. Foreign language classroom anxiety. - The Modern Language Journal, 70 (2), 125-132. https://doi. org/10.1111/j.1540-4781.1986.tbo5256.x

Huyen, Nguyen Thi Thanh; Nga, Khuat Thi Thu 2013. Learning vocabulary through games: The effectiveness of learning vocabulary through games. - Asian EFL Journal.

Jean, Gladys; Simard, Daphnée 2011. Grammar teaching and learning in L2: Necessary, but boring? - Foreign Language Annals, 44 (3), 467-494. https://doi. org/10.1111/j.1944-9720.2011.01143.x 
Ketterlinus, Leila 2017. Using Games in Teaching Foreign Languages. MA Thesis. West Point: United States Military Academy.

Kim, Bohyun 2015. Understanding Gamification. - Library Technology Reports, 51 (2). https://doi.org/10.5860/ltr.51n2

Kingisepp, Leelo; Kärtner, Piret 2015. Mängime ja keel saab selgeks ['Let's play and the Language Will be Learned']. Tallinn: Iduleht.

Kitsnik, Mare 2014. Õppematerjali mõju gümnaasiumiõpilaste õpimotivatsioonile: "Praktiline eesti keel teise keelena: B2, C1" ['The influence of learning materials on students' motivation to learn: Practical Estonian as a Second Language B2, C1']. - Tallinna Ülikooli eesti keele ja kultuuri instituudi toimetised, 16, $172-201$.

Kitsnik, Mare 2019. Eesti keele kui teise keele õppimine - kas raske töö või kerge lõbu? ['Learning Estonian as a second language - hard work or easy fun?'] - Keel ja Kirjandus, 1-2, 39-57.

Larsen-Freeman, Diane 2007. Techniques and Principles in Language Teaching. Oxford: Oxford University Press.

Lobman, Carrie; Lundquist, Matthew 2007. Unscripted Learning: Using Improv Activities Across the K-8 Curriculum. Teachers College Press.

Macedonia, Manuela 2005. Games and foreign language teaching. - Support for Learning, 20 (3), 135-140. https://doi.org/10.1111/j.0268-2141.2005.00377.x

Metslang, Helena; Kibar, Triin; Kitsnik, Mare; Koržel, Jevgenia; Krall, Ingrid; Zabrodskaja, Anastassia 2013. Kakskeelne õpe vene õppekeelega koolis. Uuringu lõpparuanne ['Bilingual learning in Russian-medium schools. Final research report']. Tallinn: Tallinna Ülikooli eesti keele ja kultuuri instituut.

Mullins, Jeffrey K.; Sabherwal, Rajiv 2018. Beyond enjoyment: A cognitive-emotional perspective of gamification. - Proceedings of the 51st Hawaii International Conference on System Sciences. https://doi.org/10.24251/HICSS.2018.152

Novak, Jelizaveta 2019. Grammatika õpetamine põhikooli eesti keele teise keelena tundides ['Teaching grammar in Estonian basic school as a second language']. Bakalaureusetöö. Tartu Ülikool. http://hdl.handle.net/10062/64584

Ojeda, Fernando Arturo 2004. The Role of Word Games in Second-Language Acquisition: Second-Language Pedagogy, Motivation, and Ludic Tasks. PhD Thesis. University of Florida.

Razin, Lyosha; Kingisepp, Leelo 2018. Igrajut vse! ['All in game’]. Tallinn: Mitteformaalne Koolituskeskus GAME club.

Richards, Jack C. 2006. Communicative Language Teaching Today. Cambridge: University Press.

Rõõm keelest ja inimestest. Mare Kitsniku blogi. http://keeljainimesed.blogspot.com/ (6.1.2020).

Rüütel, Hiie 2019. Huvitavad ja kasutatavad õppetegevused eesti keele kui teise keele tundides 11. klassi õpilaste hinnangul. Magistritöö. Tallinna Ülikool.

Sailer, Michael; Hense, Jan Ulrich; Mayr, Sarah; Mandl, Heinz 2017. How gamification motivates: An experimental study of the effects of specific game design elements on psychological need satisfaction. - Computers in Human Behavior, 69 (4), 371-380. https://doi.org/10.1016/j.chb.2016.12.033

Samperio, Nahum; Toledo, David Sarracino; Ríos, María del Rocío Garduño 2016. Students' preferences for communicative activities and teacher's frequency of communicative activity use in Tijuana. - Plurilinkgua, 12 (1), 15-33.

Schlagenhaufer, Christian; Amberg, Michael 2014. Psychology theories in gamification: A review of information systems literature. - European, Mediterranean \& Middle Eastern Conference on Information Systems, 27-28 September, Doha, Qatar.

Selliov, Rena 2016. Eesti keelest erineva emakeelega põhikooli lõpetajate eesti keele oskus ['Language proficiency of basic school graduates with a first language other than 
Estonian']. Tartu: Haridus-ja Teadusministeerium. https://www.hm.ee/sites/default/ files/hmin b1 keele tase.pdf (24.4.2020).

Sillaots, Martin 2016. Creating The Flow: The Gamification Of Higher Education Courses. Dissertations on Social Sciences, 107. Tallinn: Tallinn University.

Sooalu, Moonika 2016. Õpilaste demotivatsiooni põhjused 9. klassi eesti keele teise keelena tundides ['Reasons of Students' Demotivation in the 9th Grade Estonian as a Second Language Lessons']. Magistritöö. Tallinn: Tallinna Ülikool.

Spolin, Viola 1986. Theater Games for the Classroom. A Teacher's Handbook. Evanston, Illinois: Northwestern University Press.

Tomlinson, Brian 2012. Materials development for language learning and teaching. - Language Teaching, 45 (2), 143-179. https://doi.org/10.1017/So261444811000528

Ur, Penny 2006. Grammar Practice Activities. A Practical Quide for teachers. Cambridge.

Whittingham, Jeff; Huffman, Stephanie; Rickman, Wendy; Wiedmaier, Cheryl 2013. Technological Tools for the Literacy Classroom. IGI Global. https://doi. org/10.4018/978-1-4666-3974-4

Pirgita-Maarja Hallas on eesti keele kui teise keele õpetaja.

Jakobi 2, 51005 Tartu, Estonia

pirgita.hallas@gmail.com

Mare Kitsnik on Tartu Ülikooli eesti keele võõrkeelena didaktika vanemteadur. Jakobi 2, 51005 Tartu, Estonia

marekitsnik@gmail.com 


\title{
THE EFFECT OF GAMIFIED LEARNING ACTIVITIES ON THE ATTITUDES OF 9th GRADE PUPILS TOWARDS LESSONS OF ESTONIAN AS A SECOND LANGUAGE
}

\author{
Mare Kitsnik, Pirgita-Maarja Hallas \\ University of Tartu
}

Learning motivation and attitudes towards studying are considered to be among the essential factors influencing academic results. Despite this, teachers often underrate the part that learning activities, methods and materials play in forming pupils' motivations and attitudes (Metslang et al. 2013). Both Gardner (2007) and Dörnyei $(1994,2001)$ consider the specific learning situation, or events happening in the classroom, as an important factor of learning motivation.

This article focuses on teachers' options to affect pupils' attitudes towards Estonian lessons via gamified learning activities. The term gamification is generally defined "the use of game design elements in a nongame context" (Deterding et al., 2011). This study involved an experiment with gth graders in a Russian-language school in Tallinn, Estonia. During the three-month experiment, six learning groups had a weekly Estonian language lesson, where the language was exclusively studied with gamified learning activities. The teacher in their first year at the school prepared and taught these lessons using a variety of materials. The other Estonian lessons were taught by other teachers in a more traditional manner.

The pupils were instructed to answer a questionnaire both at the beginning and the end of the experiment. Before the experiment, 67 pupils commented on and evaluated their experiences of Estonian lessons taken during a period of eight years. After the experiment, 77 pupils commented on and evaluated their experiences of gamified Estonian lessons. The pupils evaluated the lessons in a Likert scale (1-7) according to ten factors (usefulness, necessity, interest, activeness, variance, modernity, fun, energy, atmosphere, ease) and commented the learning activities.

The pupils evaluated the traditional lessons of Estonian language as the second language rather highly. The usefulness ( 6 on average) and necessity (5.6) were evaluated the highest. Modernity (4.9.), interest (4.6), atmosphere (4.6), variance (4.4), activity (4.3) were also rated above average. Two factors had ratings beyond the average: energy (3.7) and fun (3.5).

In the gamified lessons, compared to the traditional lessons of eight years, the factor of fun increased the most (from 3.5 to 5.5 , an increase of two). The ratings of energy and ease (1.3) were also higher. However, the evaluations of usefulness and necessity of gamified lessons were lower. The average ratings of usefulness fell respectively by one (from 5.6 of the traditional lessons to 4.6) and 0.7 (from 6 to 5.3). The average evaluations of other factors did not show notable differences. Notably, evaluations varied both by groups and individually.

Keywords: learning motivation, learning activities, gamification, second language learning, Estonian language 